Research Article

\title{
A study to evaluate the in-vivo anticancer activity of ethanolic extract of Holoptelea integrifolia leaves against Ehrlich ascites carcinoma model using Swiss albino mice
}

\author{
Pramod S. G. ${ }^{1 *}$, Jayanthi M. K. ${ }^{2}$, Mruthunjaya K. ${ }^{3}$, Manjula S. N.
}

${ }^{1}$ Department of Pharmacology, DM-Wayanad institute of medical sciences, Wayanad, Kerala, India

${ }^{2}$ Department of Pharmacology, JSSMC medical college, Mysore, Karnataka, India ${ }^{3}$ Department of Pharmacognosy, JSSPC, Mysore, Karnataka, India

Received: 09 August 2016 Accepted: 13 August 2016

*Correspondence to:

Dr. Pramod S.G,

Email:drpramodgowda

@gmail.com

Copyright: (C) the author(s), publisher and licensee Medip Academy. This is an openaccess article distributed under the terms of the Creative Commons Attribution NonCommercial License, which permits unrestricted noncommercial use, distribution, and reproduction in any medium, provided the original work is properly cited.

\begin{abstract}
Background: Herbs having ethnomedical uses is one of the best approaches in searching novel anticancer drugs. The aim of the present study is to evaluate the anticancer activity of ethanolic extract of Holoptelea integrifolia leaves against Ehrlich ascites carcinoma induced liquid tumor model using Swiss Albino mice. Methods: Acute toxicity test was performed using Wistar albino rats before starting the in-vivo anticancer activity, were the MTD was more than 5000 $\mathrm{mg} / \mathrm{kg}$. Animals were divided into six groups of six animals each. $250 \mathrm{mg} / \mathrm{kg}$ and $500 \mathrm{mg} / \mathrm{kg}$ of ethanolic extract of HI leaves, was administered orally for 9 days and Cisplatin (3.5 mg/kg, i.p., single dose). Various parameters like Change in body weight, Mean Survival Time, Percentage Increase in Life Span, Hematological \& Biochemical parameters were assessed.

Results: All the parameters were considerably restored towards the normal values. HIAL500mg/kg showed more significant results than $250 \mathrm{mg} / \mathrm{kg}$. Hence $500 \mathrm{mg} / \mathrm{kg}$ was taken for combination study with standard drug Cisplatin.

Conclusions: On the basis of the above result it was suggested that, the in-vivo anticancer activity of ethanolic extract of Holoptelea integrifolia leaves possess significant anticancer property with the dose dependent effect. This may probably due to the presence of phytochemicals such as alkaloids, phenols and flavonoids.
\end{abstract}

Keywords: Holoptelea integrifolia, Cisplatin, Ethanolic extract, Ehrlich Ascites Carcinoma, Swiss albino mice

\section{INTRODUCTION}

Cancer is characterized by uncontrolled division of cells and the ability of these cells to invade other tissues, either by direct growth into adjacent tissues through invasion or by implantation into distant sites by metastasis. ${ }^{1}$ Metastasis is the major causes of death from cancer. ${ }^{2}$ It is the characteristic feature of malignant tumours. Whereas in case of benign tumours, Invasion and Metastatic stages are not observed; and even the growth of cells is selflimited.
The word 'cancer', Latin for crab, does not denote a single disease; rather it is the term used to represent a plethora of diseases in which immortalized cells continue to divide without control, thus enabling the tumour to spread beyond the organ of origin. Because the body's defence mechanism is not able to recognize the cancer cells as being foreign (rather it treats them as normal), no immune response can be initiated against them. ${ }^{3}$ This is one of the main reasons that make cancer so deadly. Currently three modalities (ionising radiations, surgery and chemotherapy) are used alone or in combination to treat cancer. The choice may depend on a number of 
factors including the type of cancer and the stage of its development. Each has its own advantages, disadvantages or limitations.

Natural products, especially plants, have been used for the treatment of various diseases for thousands of years. Terrestrial plants have been used as medicines in Egypt, China, India and Greece from ancient time and an impressive number of modern drugs have been developed from them. The first written records on the medicinal uses of plants appeared in about $2600 \mathrm{BC}^{4}$

Holoptelea integrifolia Roxb., Ulmaceae family. Various parts of Holoptelea integrifolia, a roadside plant, are indicated by Charaka, Samhitha, Sushrutha and other traditional systems for the treatment of inflammation, acid gastritis, dyspepsia, flatulence, colic, intestinal worms, vomiting, wounds, vitiligo, leprosy, filariasis, diabetes, hemorrhoids, dysmenorrhoea and rheumatism. According to literature survey, the plant Holoptelea integrifolia exhibits a wide range of biological activities which have been reported by many workers. Anticancer efficacy of bark of Holoptelea integrifolia, against 7,12dimethyl-benz (a) anthracene induced breast carcinoma in experimental rats and antitumour activity of ethanolic extract of leaves of Holoptelea integrifolia on dalton's ascitic lymphoma in swiss albino mice were reported and found to have potent anti-tumor activity. ${ }^{5}$

\section{METHODS}

\section{Collection and preparation of plant extract}

The plant material (Leaves of Holoptelea integrifolia) was collected from ODP campus, Bannimantap, Mysore district, Karnataka, India and was authenticated by Dr. M.N. Naganandini, Assistant Professor, Dept of Pharmacognosy, JSSCP, and Mysore. The leaves of plant were cleaned to remove impurities and shade dried. The coarsely powdered leaves were weighed and stored in air tight containers. The coarsely powdered shade dried leaves of the plant Holoptelea integrifolia (200 g) was extracted with ethanol by soxhlet extraction method for $25 \mathrm{~h}$. After completion of extraction the extract was filterd, concentrated using flash rotator evaporator and dried under vaccum.

\section{Cell lines}

EAC (ehrlich ascites carcinoma) cells, obtained from JSS College of Pharmacy, Mysore, Karnataka, India. The cell lines were maintained and propagated intra-peritonially by serial transplantation into adult Swiss albino mice.

\section{Animals}

The experiments were carried out on 8-10 weeks old Swiss albino mice of either sex weighing $25 \pm 5 \mathrm{gm}$ and female Wistar albino rats weighing around $175 \pm 25 \mathrm{gm}$. Animals used in the study were procured from a registered breeder. The animal care and handling was carried out in accordance to guidelines issued by the Institutional Animal Ethics Committee, JSS Medical College, Mysore, Karnataka. Animals were acclimatized to the experimental room for one week prior to the experiment. Animals were maintained under controlled conditions of temperature $\left(23 \pm 3{ }^{0} \mathrm{C}\right)$ and humidity $(50 \pm 5 \%)$ and were caged in sterile polypropylene cages containing sterile paddy husk as bedding material with maximum of four animals in each cage. The mice were fed on standard food pellets and water ad libitum.

The studies conducted were approved by the Institutional Ethical Committee, JSS Medical, College, Mysore, Karnataka.

In-vivo anticancer activity of ethanolic extract of $\mathrm{HI}$ against EAC cell lines by liquid tumor model Ehrlich ascites carcinoma (EAC) induced tumor model. ${ }^{6}$

\section{Induction of Liquid tumor}

EAC cells were aspirated from the peritoneal cavity of EAC bearing mice, after 15 days of tumor transplantation. The ascitic fluid was drawn using an 18gauge needle into a sterile syringe and a small amount was tested for microbial contamination. Total number of viable cells/ml was counted by Trypan blue and the ascitic fluid was suitably diluted in PBS to obtain a stock cell concentration of 107 cells per $\mathrm{ml}^{7}{ }^{7}$ To induce ascitic tumor $2 \times 106$ EAC cells $(0.25 \mathrm{ml}$ of stock suspension) was injected intra-peritonially to each mice. Treatment was started after 24 hour tumor inoculation and continued for 9 days.

Table 1: Treatment groups, $(n=6)$.

\begin{tabular}{|lll|}
\hline Group I & Normal & No treatment \\
\hline Group II & Control & EAC cells + D.H2O p.o \\
\hline Group III & Standard & $\begin{array}{l}\text { EAC cells + Cisplatin } \\
(3.5 \mathrm{mg} / \mathrm{kg}) \text { i.p }\end{array}$ \\
\hline Group IV & HI dose 1 & $\begin{array}{l}\text { EAC cells }+ \text { Ethanolic } \\
\text { extract }(250 \mathrm{mg} / \mathrm{kg}) \text { p.o }\end{array}$ \\
\hline Group V & HI dose 2 & $\begin{array}{l}\text { EAC cells }+ \text { Ethanolic } \\
\text { extract }(500 \mathrm{mg} / \mathrm{kg}) \text { p.o }\end{array}$ \\
\hline Group VI & $\begin{array}{l}\text { Cisplatin }+ \\
\text { selected dose } \\
\text { of HI }\end{array}$ & $\begin{array}{l}\text { EAC cells }+ \text { Cisplatin } \\
(1.75 \mathrm{mg} / \mathrm{kg}) \text { i.p }+ \text { Ethanolic } \\
\text { extract }(500 \mathrm{mg} / \mathrm{kg}) \text { p.o }\end{array}$ \\
\hline
\end{tabular}

\section{Parameters Monitored \\ $\%$ Increase in body weight as compared to day "0”weight}

Upon weighing the animals on the day of inoculation and after once in 3 days in the post inoculation period the $\%$ increase in body weight was calculated as follows: 
$\%$ increase in body $\mathrm{wt}=($ animal $\mathrm{wt}$ on respective day/animal wt on day 0)-1 x 100.

\section{Mean survival time (MST) and percentage increase in life $\operatorname{span}(\% I L S)$}

Total number of days an animal survived from the day of tumor inoculation was counted. Subsequently the mean survival time was calculated. The \%ILS was calculated as follows:

\section{$\%$ ILS $=($ MST of treated group - MST of control group $) \times 100$} MST of Control Group

An enhancement of life span by $25 \%$ or more over that of control was considered as effective anti tumor response.

\section{Haematological parameters}

In order to assess the influence of treatment on the haematological status of EAC bearing mice, blood was collected intra-cardinally from the animals into heparinised and EDTA treated micro centrifuge tubes on $10^{\text {th }}$ day and following parameters were monitored.

1. White blood cell total count.

2. Red blood cell total count.

3. Haemoglobin contents.

Biochemical estimation $^{8}$

SGPT, SGOT, ALP, Blood Urea, Serum Creatinine, Total protein. 9,10

\section{RESULTS}

Table 2: Effect of ethanolic extract of HI on body weight changes in EAC inoculated mice.

\begin{tabular}{|lllllll|}
\hline Groups & Day 3 & Day 6 & Day 9 & Day 12 & Day 15 & Day 18 \\
\hline Control & $1.57 \pm 1.23$ & $12.6 \pm 1.95$ & $27.57 \pm 2.81$ & $49.53 \pm 2.98$ & $68.41 \pm 3.87$ & $83.67 \pm 17.64$ \\
\hline Cisplatin 3.5mg/kg & $3.47 \pm 0.86$ & $12.43 \pm 0.98$ & $11.9 \pm 1.14^{\mathrm{a}}$ & $3.62 \pm 2.34^{\mathrm{a}}$ & $-10.02 \pm 3.66^{\mathrm{a}}$ & $-26.03 \pm 2.50^{\mathrm{a}}$ \\
\hline HIAL 250mg/kg & $3.28 \pm 1.19$ & $12.89 \pm 1.37$ & $23.2 \pm 2.62^{\mathrm{b}}$ & $27.75 \pm 2.69^{\mathrm{a}, \mathrm{b}}$ & $27.75 \pm 3.94^{\mathrm{a}, \mathrm{b}}$ & $27.35 \pm 5.56^{\mathrm{a}, \mathrm{b}}$ \\
\hline HIAL 500mg/kg & $3.21 \pm 1.18$ & $13.61 \pm 1.0$ & $20.63 \pm 1.2$ & $18.86 \pm 2.84^{\mathrm{a}, \mathrm{b}}$ & $14.16 \pm 1.77^{\mathrm{a}, \mathrm{b}}$ & $10.3 \pm 1.21^{\mathrm{a}, \mathrm{b}}$ \\
\hline Cisp1.75mg/kg+HIAL500 & $3.34 \pm 1.23$ & $10.6 \pm 1.77$ & $12.73 \pm 2.6^{\mathrm{a}}$ & $2.17 \pm 1.93^{\mathrm{a}}$ & $-5.01 \pm 2.43^{\mathrm{a}}$ & $-10.23 \pm 2.85^{\mathrm{a}}$ \\
\hline
\end{tabular}

*Mean \% increase in body weight compare to day ' 0 '. All the values are MEAN \pm SEM of six mice, ap < 0.05 compared to control, bp < 0.05 compared to standard. All data were analyzed by one way ANOVA followed by post hoc Tukey's multiple comparison tests.

\section{Effect of ethanolic extract of HI (HIAL) on change in the body wt in EAC inoculated mice}

Substantial increase in body weight was observed in EAC inoculated control mice with a maximum gain of $(83.67 \pm 17.64 \%)$ on day 18 compared to day 0 . The development of tumor was observed on day 6th and continued till end of study. The standard cisplatin (3.5 $\mathrm{mg} / \mathrm{kg}$ ) treatment group showed reduction in mean \% increase in body weight $(-26.03 \pm 2.50 \%)$ on day 18 when compared to day 0. Animals treated with Ethanolic extract of HI shows only slight increase in body weight of $27.35 \pm 5.56 \%(250 \mathrm{mg} / \mathrm{kg})$ and $10.30 \pm 1.21 \%(500 \mathrm{mg} / \mathrm{kg})$ on day 18 when compared to day 0 , these values were statistically significant when compared to control and standard group.

The combination treated group (Cisplatin1.75 $\mathrm{mg} / \mathrm{kg}+$ HIAL500 $\mathrm{mg} / \mathrm{kg}$ ) also showed significant reduction in mean \% increase in body weight of $10.23 \pm 2.85 \%$ on day 18 when compared to day 0 , these values were also statistically significant when compared to control and efficacy was comparable to standard group. On $12^{\text {th }}, 15^{\text {th }}$ and $18^{\text {th }}$ day all treated groups including the standard cisplatin group significantly inhibited the percentage rise in body weight as compared to control (Table 2).
Table 3: Effect of ethanolic extract of HI on Mean survival time and \% increase in life span in EAC inoculated mice.

\begin{tabular}{|lll|}
\hline Group & MST (days) & \% ILS \\
\hline Control & $21.17 \pm 0.749$ & - \\
\hline Cisp- $3.5 \mathrm{mg} / \mathrm{kg}$ & $54.50 \pm 5.937$ & $157.44 \%$ \\
\hline HIAL250 mg/kg & $38.5 \pm 1.97$ & $81.86 \%$ \\
\hline HIAL500 mg/kg & $46.5 \pm 3.71$ & $119.65 \%$ \\
\hline $\begin{array}{l}\text { CISP }(1.75 \\
\text { mg/kg)+HIAL500 }\end{array}$ & $50.83 \pm 3.71$ & $140.1 \%$ \\
\hline
\end{tabular}

*All the values are Mean \pm SEM of six mice, where ${ }^{a} \mathrm{p}<0.05$ compared to control, ${ }^{\mathrm{b}} \mathrm{p}<0.05$ compared to standard. All data were analyzed by one way ANOVA followed by post hoc Tukey's multiple comparison tests.

\section{Effect of ethanolic extract of HI leaves on mean survival time and \% increase in life span of EAC inoculated mice}

Mean survival time of EAC inoculated mice (control) was $21.17 \pm 0.749$ days. Standard cisplatin treatment at $3.5 \mathrm{mg} / \mathrm{kg}$ significantly enhanced the mean survival time to $54.50 \pm 5.937$ days when compared to control. The ethanolic extract of HI leaves significantly enhanced the MST to $38.5 \pm 1.97$ and $46.5 \pm 3.71$ days at dose $250 \mathrm{mg} / \mathrm{kg}$ and $500 \mathrm{mg} / \mathrm{kg}$ respectively, when compared to control. The combination (cisplatin $1.75 \mathrm{mg} / \mathrm{kg}+\mathrm{HIAL} 500 \mathrm{mg}$ ) also significantly increased the MST to $50.83 \pm 3.71$ days, 
when compared to control and efficacy was comparable to standard.

The percentage increase in lifespan (\% ILS) of animals treated with ethanolic extract of HI leaves at $250 \mathrm{mg} / \mathrm{kg}$ and $500 \mathrm{mg} / \mathrm{kg}$ was found to be $81.86 \%$ and $119.65 \%$ respectively. The percentage increase in lifespan of combination (cisplatin $1.75 \mathrm{mg} / \mathrm{kg}+\mathrm{HIAL} 500 \mathrm{mg}$ ) treated group was $140.1 \%$. The efficacy of combination treated group in enhancing lifespan of tumor bearing animals was comparable to that of standard (cisplatin $3.5 \mathrm{mg} / \mathrm{kg}$ ) which was $157.44 \%$ (Table 3) (Figure 1).

Table 4: Effect of ethanolic extract of HI on total RBC, WBC and HB\% in EAC inoculated mice.

\begin{tabular}{|c|c|c|c|}
\hline Treatment & $\begin{array}{l}\text { RBC }(1 \times 106 \text { cells } / \mathrm{mm} 3) \\
\text { Mean } \pm \text { sem }\end{array}$ & WBC $(1 \times 103$ cells $/ \mathrm{mm} 3)$ Mean \pm sem & Hb (gm \%) Mean \pm sem \\
\hline Normal & $4.91 \pm 0.065$ & $9.06 \pm 0.123$ & $14.01 \pm 0.142$ \\
\hline Control & $2.58 \pm 0.149^{\mathrm{a}, \mathrm{c}}$ & $24.76 \pm 0.727^{\mathrm{a}, \mathrm{c}}$ & $8.3 \pm 0.152^{\mathrm{a}, \mathrm{c}}$ \\
\hline Cisplatin(3.5mg/kg) & $4.06 \pm 0.092^{\mathrm{a}, \mathrm{b}}$ & $11.23 \pm 0.263^{\mathrm{b}}$ & $13.28 \pm 0.153^{b}$ \\
\hline HIAL $250 \mathrm{mg} / \mathrm{kg}$ & $3.53 \pm 0.183^{\mathrm{a}, \mathrm{b}}$ & $17.85 \pm 0.444^{\mathrm{a}, \mathrm{b}, \mathrm{c}}$ & $11.78 \pm 0.490^{\mathrm{a}, \mathrm{b}, \mathrm{c}}$ \\
\hline HIAL $500 \mathrm{mg} / \mathrm{kg}$ & $4.23 \pm 0.189^{b}$ & $14.21 \pm 0.740^{\mathrm{a}, \mathrm{b}, \mathrm{c}}$ & $13.03 \pm 0.420^{\mathrm{b}}$ \\
\hline $\begin{array}{l}\text { Cisplatin }(1.75 \mathrm{mg} / \mathrm{kg})+ \\
\text { HIAL }(500 \mathrm{mg} / \mathrm{kg})\end{array}$ & $4.46 \pm 0.238^{b}$ & $12.98 \pm 0.313^{\mathrm{a}, \mathrm{b}}$ & $13.36 \pm 0.296^{b}$ \\
\hline
\end{tabular}

Table 5: Effect of ethanolic extract of HI on SGOT, SGPT, ALP, S.Creatinine, S.Urea, and total protein in EAC inoculated mice.

\begin{tabular}{|lllllll|}
\hline Treatment & $\begin{array}{l}\text { SGOT } \\
\text { Mean } \pm \text { SEM }\end{array}$ & $\begin{array}{l}\text { SGPT } \\
\text { Mean } \pm \text { SEM }\end{array}$ & $\begin{array}{l}\text { ALP } \\
\text { Mean } \pm \text { SEM }\end{array}$ & $\begin{array}{l}\text { T.Protein } \\
\text { Mean } \pm \text { SEM }\end{array}$ & $\begin{array}{l}\text { S.Creatinine } \\
\text { Mean } \pm \text { SEM }\end{array}$ & $\begin{array}{l}\text { S.Urea } \\
\text { Mean } \pm \text { SEM }\end{array}$ \\
\hline Normal & $42.0 \pm 1.36$ & $64.33 \pm 2.076$ & $126.16 \pm 2.197$ & $6.78 \pm 0.288$ & $0.716 \pm 0.079$ & $34.83 \pm 3.29$ \\
\hline Control & $82.16 \pm 3.10^{\mathrm{a}, \mathrm{c}}$ & $95.16 \pm 2.03^{\mathrm{a}, \mathrm{c}}$ & $189.33 \pm 1.28^{\mathrm{a}, \mathrm{c}}$ & $12.88 \pm 0.42^{\mathrm{a}, \mathrm{c}}$ & $1.93 \pm 0.13^{\mathrm{a}}$ & $91.66 \pm 3.15^{\mathrm{a}, \mathrm{c}}$ \\
\hline $\begin{array}{l}\text { Cisplatin } \\
(3.5 \mathrm{mg} / \mathrm{kg})\end{array}$ & $52.66 \pm 1.60^{\mathrm{a}, \mathrm{b}}$ & $70.33 \pm 1.25^{\mathrm{b}}$ & $129.66 \pm 2.34^{\mathrm{b}}$ & $7.43 \pm 0.25^{\mathrm{b}}$ & $2.53 \pm 0.17^{\mathrm{a}}$ & $110.5 \pm 3.27^{\mathrm{a}, \mathrm{b}}$ \\
\hline $\begin{array}{l}\text { HIAL } \\
250 \mathrm{mg} / \mathrm{kg}\end{array}$ & $66.16 \pm 2.22^{\mathrm{a}, \mathrm{b}, \mathrm{c}}$ & $77.5 \pm 2.33^{\mathrm{a}, \mathrm{b}}$ & $147.66 \pm 3.08^{\mathrm{a}, \mathrm{b}, \mathrm{c}}$ & $8.93 \pm 0.45^{\mathrm{a}, \mathrm{b}}$ & $1.35 \pm 0.15^{\mathrm{a}, \mathrm{c}}$ & $64.33 \pm 4.24^{\mathrm{a}, \mathrm{b}, \mathrm{c}}$ \\
\hline $\begin{array}{l}\text { HIAL } \\
500 \mathrm{mg} / \mathrm{kg}\end{array}$ & $54.83 \pm 2.3^{\mathrm{a}, \mathrm{b}}$ & $72.5 \pm 2.09^{\mathrm{b}}$ & $135.83 \pm 3.63^{\mathrm{b}}$ & $8.13 \pm 0.46^{\mathrm{b}}$ & $1.06 \pm 0.08^{\mathrm{b}, \mathrm{c}}$ & $45.66 \pm 2.94^{\mathrm{b}, \mathrm{c}}$ \\
\hline $\begin{array}{l}\text { Cisplatin } \\
(1.75 \mathrm{mg} / \mathrm{kg})+\end{array}$ & $51.66 \pm 2.57^{\mathrm{b}}$ & $68.83 \pm 3.01^{\mathrm{b}}$ & $132.83 \pm 2.6^{\mathrm{b}}$ & $8.82 \pm 0.32^{\mathrm{b}}$ & $1.37 \pm 0.07^{\mathrm{a}, \mathrm{c}}$ & $49.83 \pm 3.87^{\mathrm{b}, \mathrm{c}}$ \\
$\begin{array}{l}\text { HIAL } \\
(500 \mathrm{mg} / \mathrm{kg})\end{array}$ & & & & & & \\
\hline
\end{tabular}

*All the values are Mean \pm SEM of six mice ${ }^{\text {a }} \mathrm{p}<0.05$ compared to normal, ${ }^{\mathrm{b}} \mathrm{p}<0.05$ compared to control, ${ }^{\mathrm{c}} \mathrm{p}<0.05$ when compared to standard. The data were analyzed by one way ANOVA followed by post hoc Turkey's multiple comparison tests.

\section{Effect of ethanolic extract of HI on hematological parameters in EAC inoculated mice}

To assess the effect of ethanolic extract of Holoptelea Integrifolia leaves on hematological parameters (total RBC, WBC and hemoglobin content) of EAC inoculated mice. Hematological parameters are checked on 10th day of tumor inoculation.

\section{Effect on total RBC}

A significant reduction in total RBC count was observed in EAC inoculated control mice $(2.58 \pm 0.149)$ when compared with the normal mice $(4.91 \pm 0.06)$. Treatment with cisplatin $3.5 \mathrm{mg} / \mathrm{kg}$ significantly reversed this reduction to $(4.06 \pm 0.09)$ as compared to Control.
Ethanolic extracts of $\mathrm{HI}$ at both doses increased the total RBC count to near normal and the efficacy was comparable with standard cisplatin. Combination (cisplatin $1.75 \mathrm{mg} / \mathrm{kg}+$ HIAL $500 \mathrm{mg} / \mathrm{kg}$ ) treated group also significantly reversed the RBC count to $4.46 \pm 0.23$, when compared to control and was not significant to standard (Table 4) (Figure 2).

\section{Effect on total WBC}

A significant increase in total WBC count was observed in EAC inoculated control mice $(24.76 \pm 0.727)$ when compared to normal animal $(9.06 \pm 0.12)$. Standard Cisplatin treatment at a dose of $3.5 \mathrm{mg} / \mathrm{kg}$ significantly reversed the tumor induced elevation in WBC count to $(11.23 \pm 0.26)$ when compared with control. Both doses of Ethanolic extract of $\mathrm{HI}$ and their combination treated 
groups significantly reversed the elevated WBC, when compared to control (Table 3) (Figure 2).

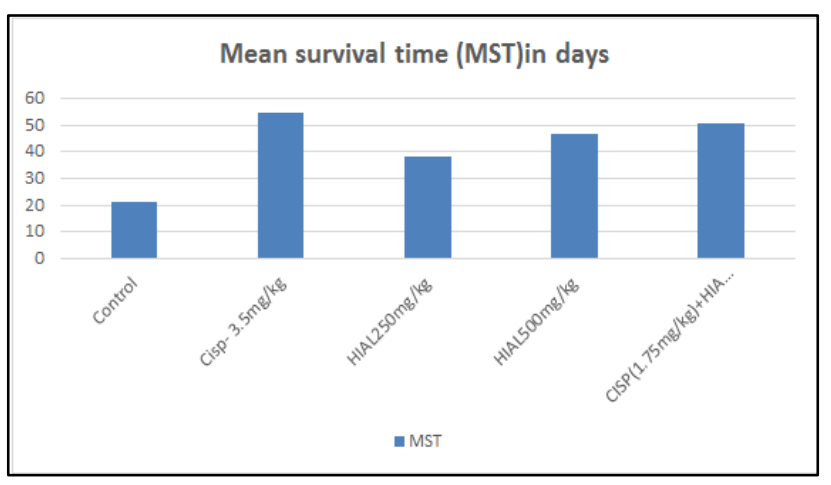

Figure 1: Mean survival time.

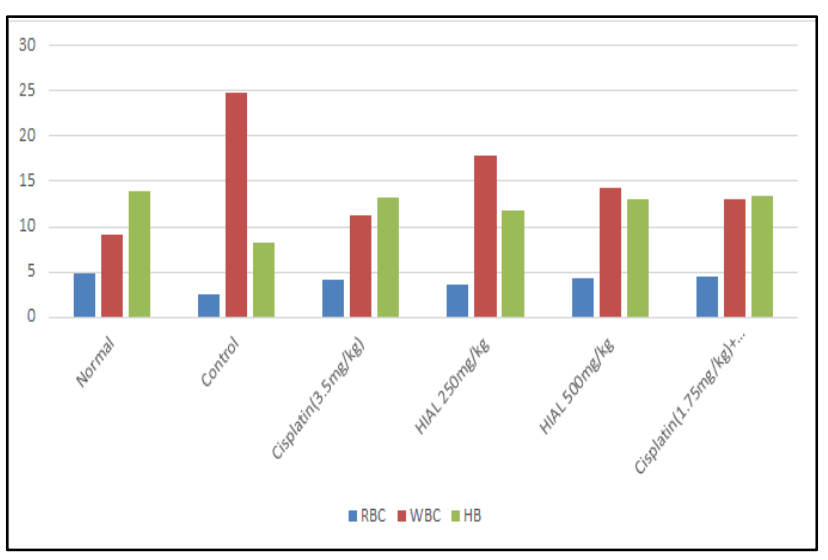

Figure 2: Hematological values.

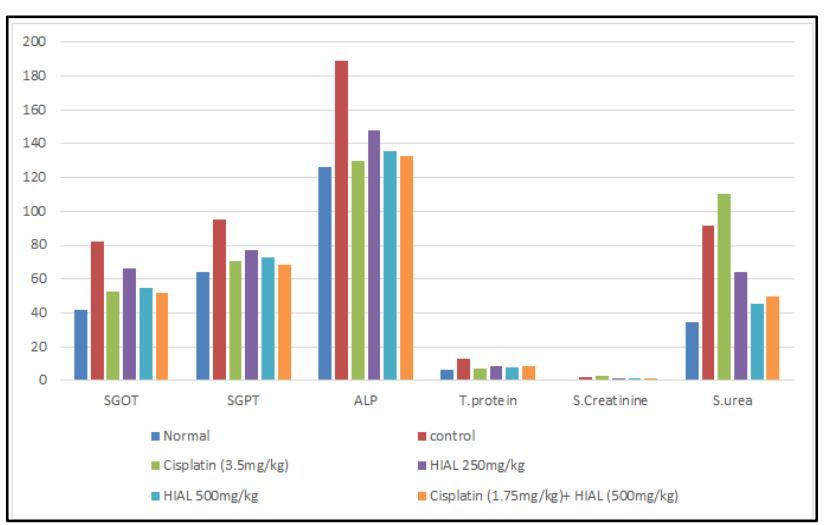

Figure 3: Biochemical values.

\section{Effect on hemoglobin content}

A significant reduction in hemoglobin level was observed in EAC inoculated control $(8.30 \pm 0.15)$ mice as compared to normal $(14.01 \pm 0.14)$. Standard cisplatin treatment at a dose of $3.5 \mathrm{mg} / \mathrm{kg}$ significantly reversed the tumor induced reduction in hemoglobin level to $(13.28 \pm 0.15)$ when compared to control. Both doses of Ethanolic extract of $\mathrm{HI}$ and their combination treated groups significantly increased the hemoglobin level, when compared to control (Table 3) (Figure 2).

\section{Effect of Ethanolic extract of HI on Biochemical parameters in EAC inoculated mice}

To assess the influence of HI treatment on Biochemical parameters, SGOT, SGPT, ALP, S. Creatinine, S. Urea, and total protein content of all the treatment groups were checked on $10^{\text {th }}$ day of tumor inoculation.

\section{Effect on serum glutamate oxalo acetic transaminase (SGOT)}

A significant increase in serum SGOT level was observed in EAC inoculated control mice $(82.16 \pm 3.1)$ when

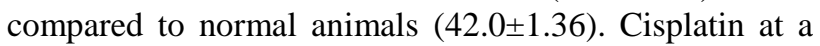
dose of $3.5 \mathrm{mg} / \mathrm{kg}$ significantly reversed the tumor induced elevation in SGOT level $(52.66 \pm 1.6)$ when compared with control. Ethanolic extract of $\mathrm{HI}$ at both doses significantly decreased the elevated SGOT level compared to control. The Ethanolic extract in combination with cisplatin also showed significant reduction in SGOT level when compared to control (Table 4) (Figure 3).

\section{Effect on Serum glutamate pyruvate transaminase (SGPT)}

A significant increase in serum SGPT level was observed in EAC inoculated control mice $(95.16 \pm 2.04)$ when compared to normal animals $(64.33 \pm 2.076)$. Cisplatin at a dose of $3.5 \mathrm{mg} / \mathrm{kg}$ significantly reversed the tumor induced elevation in SGPT level $(70.33 \pm 1.25)$ when compared with control. Ethanolic extract of HI at both doses significantly decreased the elevated SGPT level compared to control. The Ethanolic extract in combination with cisplatin also showed significant reduction in SGPT level when compared to control and decrease SGPT level was comparable with standard. (Table 4) (Figure 3).

\section{Effect on Alkaline phosphatase (ALP)}

A significant increase in serum ALP level was observed in EAC inoculated control mice $(189.3 \pm 1.28)$ when compared to normal animal (126.16 \pm 2.19$)$. Standard cisplatin treatment at a dose of $3.5 \mathrm{mg} / \mathrm{kg}$ significantly reversed the tumor induced elevation in ALP level $(129.66 \pm 2.34)$ when compared with control. Ethanolic extract of $\mathrm{HI}$ at both doses significantly decreased the elevated ALP level compared to control. The Ethanolic extract in combination with cisplatin also showed significant reduction in ALP level when compared to control (Table 4) (Figure 3).

\section{Effect on serum creatinine}

A significant increase in $\mathrm{S}$. Creatinine level was observed in EAC inoculated control mice $(1.93 \pm 0.135)$ when 
compared to normal animals $(0.716 \pm 0.079)$. Treatment with cisplatin shows significant increase in S. Creatinine levels $(2.53 \pm 0.172)$ indicating cisplatin induced Nephrotoxicity. But treatment with ethanolic extract of $\mathrm{HI}$ tends to lower the elevated S. Creatinine levels when compared to control and standard groups. The Ethanolic extract in combination with $1.75 \mathrm{mg} / \mathrm{kg}$ of cisplatin also showed reduction in elevated levels of $\mathrm{S}$. Creatinine when compared to standard group (Table 5) (Figure 3).

\section{Effect on serum urea}

A significant increase in Serum Urea level was observed in EAC inoculated control mice $(91.66 \pm 3.158)$ when compared to normal animals $(34.83 \pm 3.29)$. Treatment with cisplatin shows significant increase in Serum Urea levels (110.5 \pm 3.273$)$ indicating cisplatin induced Nephrotoxicity. But treatment with ethanolic extract of $\mathrm{HI}$ tends to lower the elevated S. Urea levels when compared to control and standard groups. The ethanolic extract in combination with $1.75 \mathrm{mg} / \mathrm{kg}$ of cisplatin also showed reduction in elevated levels of $\mathrm{S}$. Urea when compared to standard group (Table 4) (Figure 3).

\section{Effect on total protein}

Standard cisplatin showed significant decrease in Total Protein levels $(7.43 \pm 257)$ when compared to control (12.88 \pm 0.424$)$. Treatment with Ethanolic extract of HI at both the doses and in combination with cisplatin also showed significant decrease in Total. Protein levels when compared to control (Table 5) (Figure 3).

\section{DISCUSSION}

Traditional plants might have provide useful sources for developing new anticancer drugs and could be a good alternative to existing lines of cancer therapies. ${ }^{11}$ The search for a selective and less toxic molecule for cancer treatment is an ongoing process. In the present study the in-vivo anticancer activity of ethanolic extract of leaves of Holoptelea integrifolia (HIAL) plant was tested against EAC cell lines. Ethanolic extract of HI was screened for its anticancer activity against EAC cell lines in Trypan blue dye exclusion method. $61.07 \%$ cytotoxicity was observed at the concentration $200 \mu \mathrm{g} / \mathrm{ml}$. The extract may produced substantial injury to the membrane and might have enhanced the apoptotic pathway in EAC cells. In this Ascites tumor model, a substantial increase in body weight of the animals was observed in EAC bearing control mice owing to the rapid and progressive accumulation of Ascites tumor cells. Treatment with ethanolic extract $(500 \mathrm{mg} / \mathrm{kg})$ of $\mathrm{HI}+$ cisplatin $(1.75 \mathrm{mg} / \mathrm{dl})$ caused marked reduction in the body weight of the animal as compared to ethanolic extract $(250 \mathrm{mg} / \mathrm{kg}, 500 \mathrm{mg} / \mathrm{kg})$ alone indicating the features of inhibition of tumor cell progression. MST of tumor bearing mice was observed at both the ethanolic extract doses but significant enhancement of MST was seen in combination group (50.85 days) compared to contol group (21.17 days) and standard group (54.5 days). The percent increase in life span (\%ILS) of tumor bearing mice, following treatment with HIAL $500 \mathrm{mg} / \mathrm{kg}$ and combination treated group was found to be $119.65 \%$ and $140.1 \%$ respectively. Prolongation of life span is a reliable criteria for judging the anticancer efficacy of any compound. ${ }^{12}$ An enhancement of life span by $25 \%$ or more over that of control was considered as effective antitumor response. In the present study HI ethanolic extract meets this criteria. Myelosuppression and anemia have been frequently observed in ascites carcinoma. In EAC control mice elevated WBC count, and reduced hemoglobin and RBC count was observed. The anemia occurs in cancer is mainly due to decreased absorption of iron or increased hemolysis and the elevated levels WBC is due to increased immune response. ${ }^{13}$ The major problems of cancer chemotherapy with the conventional drugs are myelosuppression and anemia. Administration of HIAL reverted back the hemoglobin content, RBC and WBC counts to near normalcy indicating the efficacy of the test drug to protect the hemopoietic system. The elevated levels of SGOT, SGPT and ALP found in tumor bearing animals are attribute to secondary carcinoma and metastasis. ${ }^{14}$ The activities of liver marker enzymes are correlated to the degree of malignancy and can be used as an indicator for diagnosis and prognosis of cancer. Treatment with HIAL reverted back the elevated levels of serum hepatic marker enzymes to near normalcy, this could be due to the inhibition of tissue necrosis or cell injury or cancer cell growth resulting in altered membrane permeability leading to prevention of enzyme leakage. The standard drug had shown elevation in the levels of S. Urea and S. Creatinine levels indicating the nephrotoxic effect of cisplatin but HIAL also restored these parameters to near normal levels indicating its less nephrotoxic effect toxic effect.

\section{CONCLUSION}

On the basis of the above result it was suggested that, the in-vivo anticancer activity of ethanolic extract of Holoptelea integrifolia leaves possess significant anticancer property with the dose dependent effect. This may probably due to the presence of phytochemicals such as alkaloids, phenols and flavonoids. Further isolation and purification of bioactive compound from Holoptelea integrifolia may reveal the presence of potent novel anticancer agent and also to explore the exact mechanism of action of the anticancer activity.

\section{ACKNOWLEDGEMENTS}

Authors would like to thankful to all the staff and postgraduate students of Department of Pharmacology, JSSMC, Mysore. Dr. R.N. Suresha, Dr. Kalabharathi H.L., Dr. Satish A.M., Dr. Pushpa V. H., Dr. Prathima C, Dr. Vinod, Dr. Vaibhavi, Dr. Padmaja Shetty for their valuable support and guidance during research work. The authors are grateful Dr. S. N. Manjula. Department of 
Pharmacology, JSSPC, Mysore for their expert advice during the study.

Funding: No funding sources

Conflict of interest: None declared

Ethical approval: The study was approved by the Institutional Ethics Committee JSS medical college, Mysore, Karnataka, India

\section{REFERENCES}

1. Freemantle SJ, Liu X, Feng Q, Galimberti F, Blumen S, Sekula D, Kitareewan S, Dragnev KH, Dmitrovsky EJ. Cyclin degradation for cancer therapy and chemoprevention. Cell Biochem. 2007;102(4):869-77.

2. Available at: http://www.who.int/mediacentre/factsheets/fs297/en/ index.html-accessed 20/8/ 2011.

3. Pratt WB, Ruddon RW, Ensminger WD and Maybaum J. The Anticancer Drugs. Oxford University Press; USA, 1994.

4. Jayaseelan RS, Vijayan PF, Mathesvaran MS, Padikkala J. Cytotoxic and antitumor activity of methanolic extract desmodium triangulare. Root. International Journal of Pharmacy and Pharmaceutical Sciences; 2012;4(3):0975-1491.

5. Sharma J, Singh V. Holoptelea integrifolia: an overview. European Journal of Applied Sciences. 2012;4(1):42-6.

6. Jagetia GC, Venkatesha VAK. Enhancement of radiation effect by Aphanamixis polystachya in mice transplanted with Ehrlich ascites carcinoma. Biol Pharma Bull. 2005;28(1):69-77.
7. HiMedia Laboratories. Available at: http://himedialabs.com accessed 13/1/14.

8. Swemed Biomedicals Pvt. Ltd. Available at: http:// www.swemedbio.com/ pdf/ SGOT_KIT.pd. Accessed 25/1/14.

9. Dasgupta T, Rao AR, Yadava PK. Modulatory effect of Henna leaf (Lawsonia inermis ) on drug metabolizing phase I and phase II enzymes, antioxidant enzymes, lipid peroxidation and chemically induced skin and forestomach papillomagenesis in mice. Molecular and cellular biochemistry. 2003;245:11-22.

10. Pariani S, Buscaglia M, Piantanida M, Simoni G. Cyclophosphamide increases the frequency of sister chromatid exchange in direct preparations of human chorionic villi in the absence of supplementary enzymatic activation system. I Med Genet. 1992;29:109-11.

11. Kim J, Park E. Chem Antican Agent. J Curr Med. 2002;2:485-537.

12. Gupta M, Mazumder UK, Sambath kumar R, Sivakumar T, Vamsi MLM. Antitumor activity and antioxidant status of Caesalpinia bonducella against ehrlich ascites carcinoma in swiss albino mice. J Pharmacol Sci. 2004;94:177-84.

13. Price VE, Greenfield RE. Anemia in cancer. Adv Cancer Res. 1958;2:229-53.

14. El-Beshbishy HA. The effect of dimethyl dimethoxy biphenyl dicarboxylase against tamoxifen-induced liver injury in rats. DDB use is curative or protective. J biochem Mol Biol. 2005;8:300-6.

Cite this article as: Pramod SG, Jayanthi MK, Mruthunjaya K, Manjula SN. A study to evaluate the in-vivo anticancer activity of ethanolic extract of Holoptelea integrifolia leaves against Ehrlich ascites carcinoma model using Swiss albino mice. Int J Basic Clin Pharmacol 2016;5:1739-45. 